\title{
Urethral tumour: rare images of unaware entity
}

\author{
Jai Prakash, Manoj Kumar, Satyanarayan Sankhwar, Vishwajeet Singh
}

Department of Urology, King George Medical University, Lucknow, Uttar Pradesh, India

\section{Correspondence to}

Dr Jai Prakash, drjpswami@ gmail.com
To cite: Prakash J, Kumar M, Sankhwar S, et al. BMJ Case Rep Published online: [please include Day Month Year] doi:10.1136/ bcr-2013-010493

\section{DESCRIPTION}

A 55-year man with a history of thin stream of urine and dysuria for the last 7 years presented with mild haematuria followed by acute urinary retention for 2 days. Clinical examination showed indurated mass with urethrocutaneous fistula in perineum (figure 1A). Per-urethral catheter could not be negotiated and so urine was drained by suprapubic catheterisation. Retrograde urethrogram and voiding cystourethrogram were suggestive of filling defect in bulbar urethra (figure 1B,C). Urethroscopy (figure 2A) revealed a broad base lesion arising from dorsal and left lateral wall of distal bulbar urethra occluding the lumen of urethra. MRI showed a low signal intensity heterogeneous mass of bulbo-membranous urethra that invaded into spongiosa and penile skin with bilateral inguinal node involvement (figure 2B). Biopsy was suggestive of transitional cell carcinoma (figure 3). The patient was counselled for cystoprostectomy with total penectomy but he refused. He received $60 \mathrm{~Gy}$ of radiotherapy in 30 fractions followed by six cycles of methotrexate, vinblastine, doxorubicin and cisplatin. Follow-up at 3 months showed good local response and absence of progression in regional nodes. Urethral carcinoma is very rare and is less common in men than in women. ${ }^{1}$ Symptoms are non-specific ${ }^{2}{ }^{3}$ and unaware to patients and so presentation is usually delayed. $^{2}$ Because of difficulty in achieving local control, ${ }^{1}$ proximal urethral cancer carries a worse prognosis than distal. ${ }^{45}$ However, cases of a curative

\section{Learning points}

\section{Uretheral cancer}

- Uretheral cancer is a rare disease and symptoms are usually non-specific.

- Presentation is usually delayed because of unawareness of symptoms.

- Proximal tumours have a worse prognosis then distal tumours.

- Radical surgery is necessary to achieve good local control in proximal cancers.

- Penile preserving surgery is adequate for local control in distal tumours.

- Overall prognosis is poor.
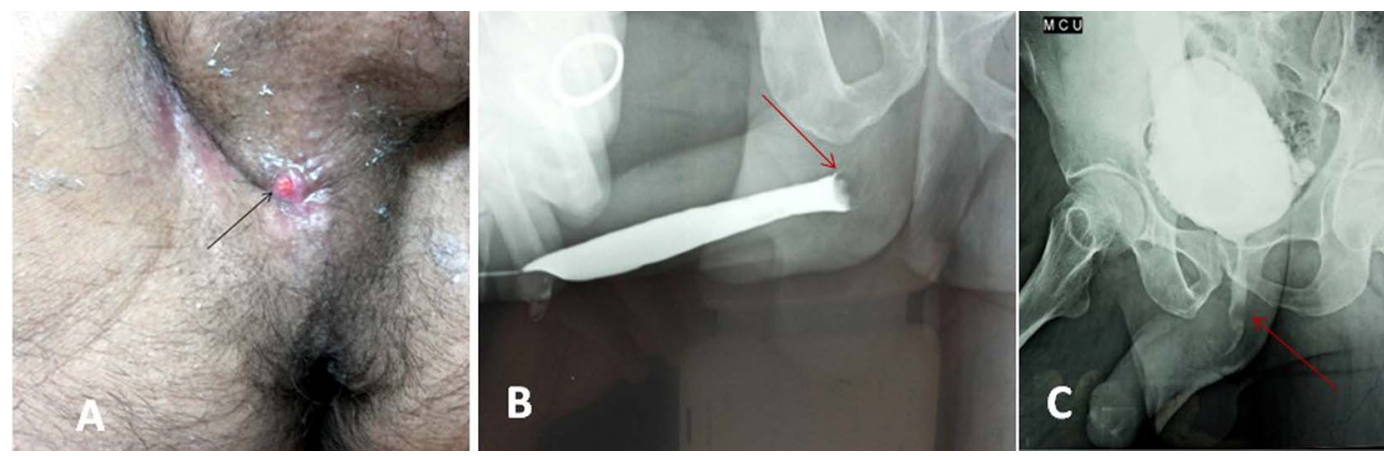

Figure 1 (A) Urethrocutaneous fistula at peno-bulbar junction. (B) Retrograde urethrogram showing filling defect at peno-bulbar junction. (C) Voiding cystourethrogram showing filling defect in bulbar urethra.
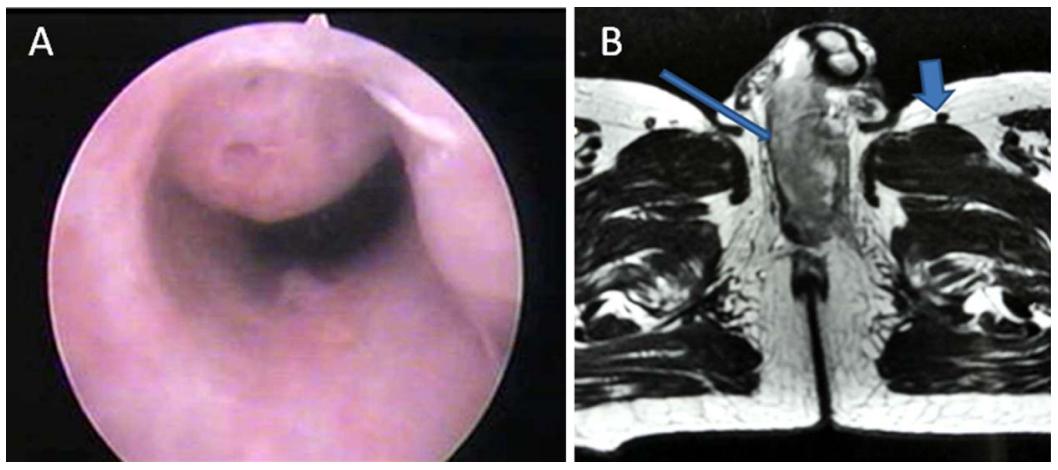

Figure 2 (A) Urethroscopy showing growth arising from dorsal and left lateral wall of bulbar urethra. (B) MRI shows that the mass (large arrow) occupies the corpus spongiosum and adjacent skin but has not invaded the corpora cavernosa with bilateral inguinal lymph node involvement (small arrow). 


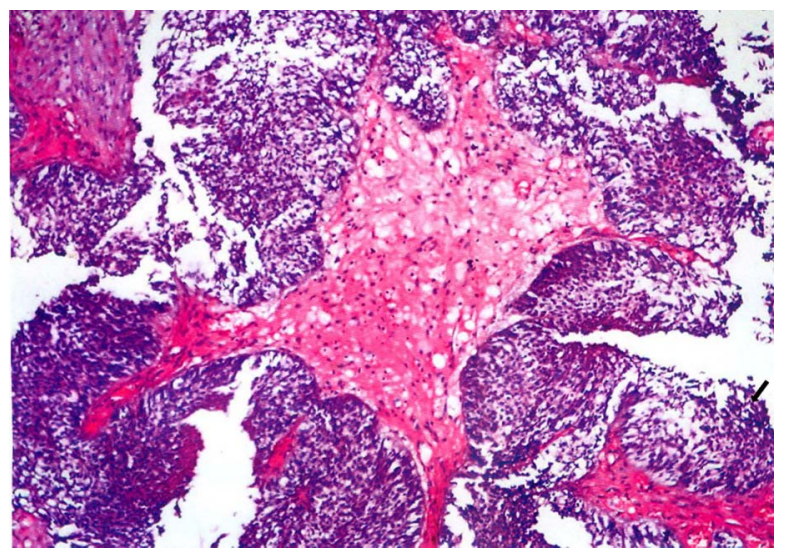

Figure 3 Histopathology report showing proliferated transitional epithelial cells disposed in papilla formation (arrow) and lamina properia infiltration.

response to chemo-radiotherapy alone have been reported ${ }^{6}$ but radical cystoprostectomy, pelvic lymphadenectomy and total penectomy is a standard treatment option for proximal urethral cancers. ${ }^{1}$
Contributors All authors participated in writing the manuscript and treating the patient.

Funding None.

Competing interests None.

Patient consent Obtained.

Provenance and peer review Not commissioned; externally peer reviewed.

\section{REFERENCES}

1 Dinney $C P$, Johnson $D E$, Swanson DA, et al. Therapy and prognosis for male anterior urethral carcinoma: an update. Urology 1994;43:506-14.

2 Farrer JH, Lupu AN. Carcinoma of deep male urethra. Urology 1984;24:527-31.

3 Zeidman EJ, Desmond P, Thompson IM. Surgical treatment of carcinoma of the male urethra. Urol Clin North Am 1992;19:359-72.

4 Dalbagni G, Zhang ZF, Lacombe L, et al. Male urethral carcinoma: analysis of treatment outcome. Urology 1999;53:1126-32.

5 Gillitzer R, Hampel C, Wiesner C, et al. Single-institution experience with primary tumours of the male urethra. BJU Int 2008;101:964-8.

6 Oberfield RA, Zinman LN, Leibenhaut M, et al. Management of invasive squamous cell carcinoma of the bulbomembranous male urethra with coordinated chemo-radiotherapy and genital preservation. Br J Urol 1996;78:573-8.

7 Hussein AM, Benedetto P, Sridhar KS. Chemotherapy with cisplatin and 5-fluorouracil for penile and urethral squamous cell carcinomas. Cancer 1990;65:433-8.

Copyright 2013 BMJ Publishing Group. All rights reserved. For permission to reuse any of this content visit http://group.bmj.com/group/rights-licensing/permissions.

BMJ Case Report Fellows may re-use this article for personal use and teaching without any further permission.

Become a Fellow of BMJ Case Reports today and you can:

- Submit as many cases as you like

- Enjoy fast sympathetic peer review and rapid publication of accepted articles

- Access all the published articles

- Re-use any of the published material for personal use and teaching without further permission

For information on Institutional Fellowships contact consortiasales@bmjgroup.com

Visit casereports.bmj.com for more articles like this and to become a Fellow 